\title{
Development of a Consolidated Anaerobic Digester and Microbial Fuel Cell to Produce Biomethane and Electricity from Cellulosic Biomass Using Bovine Rumen Microorganisms
}

\author{
Rebecca Chung1, Eunice Yujin Kang', Yun Jae Shin ${ }^{1}$, Justin Jong Park ${ }^{3}$, Peter Sang Park ${ }^{4}$, \\ Chang Hyun Han ${ }^{5}$, Byungjun Kim ${ }^{5}$, Seog In Moon ${ }^{6}$, Jooheon Park ${ }^{7}$, Paul Sung Chung8 \\ ${ }^{1}$ Centreville High School, Clifton, VA, USA \\ ${ }^{2}$ West Springfield High School, Springfield, VA, USA \\ ${ }^{3}$ Department of Biological Science, University of Southern California, Los Angeles, CA, USA \\ ${ }^{4}$ Biology, College of Arts \& Science, Cornell University, Ithaca, NY, USA \\ ${ }^{5}$ Biological Science, Mellon College of Science, Carnegie Mellon University, Pittsburgh, PA, USA \\ ${ }^{6}$ Department of Biology, Amherst College, Amherst, MA, USA \\ ${ }^{7}$ Biology, Science Program, University of Alberta, Edmonton, Canada \\ ${ }^{8}$ Fuzbien Technology Institute (FTI), Rockville, USA \\ Email: paulschung08@gmail.com
}

How to cite this paper: Chung, R., Kang, E.Y., Shin, Y.J., Park, J.J., Park, P.S., Han, C.H., Kim, B., Moon, S.I., Park, J. and Chung, P.S. (2019) Development of a Consolidated Anaerobic Digester and Microbial Fuel Cell to Produce Biomethane and Electricity from Cellulosic Biomass Using Bovine Rumen Microorganisms. Journal of Sustainable Bioenergy Systems, 9, 17-28. https://doi.org/10.4236/jsbs.2019.92002

Received: December 7, 2018

Accepted: April 13, 2019

Published: April 16, 2019

\section{Copyright $\odot 2019$ by author(s) and} Scientific Research Publishing Inc. This work is licensed under the Creative Commons Attribution International License (CC BY 4.0).

http://creativecommons.org/licenses/by/4.0/

c) (i) Open Access

\begin{abstract}
Microbial fuel cells (MFCs) are bioelectrochemical systems that convert chemical energy contained in organic matter into electrical energy by using the catalytic (metabolic) activity of living microorganisms. Mediator-less two chamber H-type MFCs were constructed in the current study, using dairy digester microbial population as anode inocula to convert finely ground pine tree (Avicel) at $2 \%(\mathrm{w} / \mathrm{v})$ to electricity. MFCs were placed at $37^{\circ} \mathrm{C}$ and after the circuit voltage was stabilized on $\mathrm{d} 9$, bovine rumen microorganisms cultured anaerobically for $48 \mathrm{hrs}$ in cellulose broth media were added to treatment group of MFC at $1 \% \mathrm{v} / \mathrm{v}$ dosage. MFC power and current across an external resistor were measured daily for $10 \mathrm{~d}$. At the end of incubation on $\mathrm{d} 19$ head space gas and anode chamber liquid solutions were collected and analyzed for total gas volume and composition, and volatile fatty acids, respectively. Addition of enriched rumen microorganisms to anaerobic anode chamber increased cellulose digestibility and increased both $\mathrm{CO}_{2}$ and methane production; however, it decreased the methane to $\mathrm{CO}_{2}$ ratio. Over the experimental period, electricity generation was increased with rumen microorganism addition, and power density normalized to anode surface area was 17.6 to $67.2 \mathrm{~mW} / \mathrm{m}^{2}$ with average of $36.0 \mathrm{~mW} / \mathrm{m}^{2}$ in treatment, while control
\end{abstract}


group had 3.6 to 21.6 (AVE 12.0$) \mathrm{mW} / \mathrm{m}^{2}$. These observations imply that biocatalysis in MFCs requires additional cellulolytic activities to utilize structural biomass in bioenergy production.

\section{Keywords}

Microbial Fuel Cells (MFCs), Bovine Rumen Bacteria, Bioenergy

\section{Introduction}

Fossil fuels including petroleum, coal, and natural gas contribute about $80 \%$ of the global primary energy use [1]. The use of fossil fuels adds greenhouse gases such as carbon dioxide $\left(\mathrm{CO}_{2}\right)$, methane $\left(\mathrm{CH}_{4}\right)$ and nitrous oxide $\left(\mathrm{N}_{2} \mathrm{O}\right)$ to atmosphere [2]. Fossil fuel combustion and natural gas and petroleum systems represented $94 \%$ to $96 \%$ of greenhouse emission in the USA (EPA, 2016). Greenhouse gases absorb infrared radiation and consequently impact global warming [3]. In addition to environmental issues, the future depletion of fossil fuel is another concern. Goldemberg (2007) expected fossil fuel reserves might run out in 100 years or more. For these reasons, many researches have been studied to develop new types of energy source as alternative to fossil fuels [4] [5] and technologies which generate clean and sustainable energy [6].

Cellulosic biomass is the most abundant renewable energy resources on the earth, and cellulose is a significant component in solid waste products of municipal, agricultural and industrial activities and wastewater [7]. The U.S. Departments of Agriculture and Energy estimated the annual available biomass feedstock could displace over $30 \%$ of the petroleum consumption in the United States [8]. Furthermore, cellulose use in energy production is carbon neutral which can mitigate global warming [9]. Chemical and biological approaches to develop sustainable energy production from cellulosic materials encountered technical and economical hurdles [10] [11], however cellulosic biomass could be converted to bioethanol [12], biodiesel [13], biohydrogen [14], and electricity [9].

Anaerobic digester $(\mathrm{AD})$ is a bioprocess in wastewater treatment processes and has been widely used in the treatment of solid wastes such as livestock and poultry waste [15] [16] [17]. The focus on AD has been switched to energy production such as bioconversion of waste solids into methane gas, and has been developed for industrial scale [18]. Microbial fuel cell (MFC) is also a technology for both energy production and environment protection by generating electricity and treating the organic wastewater simultaneously using microorganisms [19]. MFC is a bioelectrochemical reactor that converts organic material directly into electricity by electrochemically active microorganisms [20].

Recently, the intergradation of $\mathrm{AD}$ and MFC has been studied to maximize the energy recovery [18] [21], minimize pollutants and recover inorganic nutrients in end products of waste treatments [22] [23]. AD efflux has provided 
electrochemically active microorganisms for anode reduction, and anode function is stable during the more than $300 \mathrm{~d}$ studies [21] [23] [24]. Use of chemical energy in cellulosic biomass requires cellulose degradation; however, microorganisms found electrochemically active do not show cellulolytic activity, and require products of cellulose fermentation as electron donors to generate electricity in MFC [25]. Prior to Biomethane production from cellulose in AD, cellulose also need to be degraded to glucose or lower molecular compounds.

Ruminant animals such as cow, goat and sheep have been adapted to digest cellulosic biomass with cellulose hydrolysis by microorganisms in their digestive chamber, the rumen. The rumen microorganisms include both strict and facultative anaerobes, which effectively hydrolyze cellulose and conserve energy via anaerobic respiration or fermentation [26]. Rumen fluid from cow [7] [27] or goat had been studied for electricity generation from cellulose or cellulosic biomass. In all these studies, rumen microorganism was tested as both cellulose degrading and electron transferring microorganisms at the same time, and observations might not reflect the cellulosic electricity generation and bioCH${ }_{4}$ production in consolidated AD and MFC (AD-MFC).

Pursuing synergetic and symbiotic consortium of cellulosic biomass degrading microorganisms and electrochemically active microorganism in AD-MFC, the addition of cellulolytic microorganism to electrochemically active AD microbial population could be a reasonable approach. The current study hypothesized that cellulolytic rumen microorganisms might ferment cellulosic biomass in $\mathrm{AD}$ microbial population and provide fermentation products as electron donor or methanogenic precursors to $\mathrm{AD}$ microorganisms and generate greater electricity and improve methanogenesis in AD-MFC. Therefore, in the current study, MFCs were constructed with anaerobic digester microorganisms as anolyte and cellulose as electron donor, and then rumen fluid enriched in cellobiose medium was added to anolyte to investigate whether inoculation of cellulolytic rumen fluid would improve cellulose degradation in AD-MFC, and increase electricity generation and/or bio $\mathrm{CH}_{4}$ production by $\mathrm{AD}$ microorganism population.

\section{Materials \& Methods}

\subsection{Microorganisms and Culture Media}

Anaerobic digester fluid was collected from a dairy farm for MFC anode chamber inoculum. Under flushing of $\mathrm{CO}_{2}$ gas through heated copper column $\left(350^{\circ} \mathrm{C}\right)$, anaerobic digester fluid was filtered through 4 layers of cheesecloth and glass wool, then bubbled with $\mathrm{CO}_{2}$ gas until transferred to MFCs.

Fifty $\mathrm{mL}$ of rumen fluid was collected from a non-lactating fistulated Holstein cow fed a forage diet. Rumen fluid was bubbled with $\mathrm{CO}_{2}$ and under flushing of $\mathrm{CO}_{2}$ mixed with a commercial blender and filtered through 4 layers of cheese cloth. Ten $\mathrm{mL}$ of strained rumen fluid was inoculated to $90 \mathrm{~mL}$ of anaerobic medium containing $1 \%$ cellobiose, $0.048 \% \mathrm{KH}_{2} \mathrm{PO}_{4}, 0.048 \% \mathrm{~K}_{2} \mathrm{HPO}_{4}, 0.048 \%\left(\mathrm{NH}_{4}\right)_{2} \mathrm{SO}_{4}$, $0.096 \% \mathrm{NaCl}, 0.5 \%$ Trypticase peptone, $5 \%$ yeast extract, $0.05 \%$ cysteine- $\mathrm{HCl}$, 
$0.013 \% \mathrm{CaCl}_{2} \cdot 2 \mathrm{H}_{2} \mathrm{O}, 0.02 \% \mathrm{MgSO}_{4} \cdot 7 \mathrm{H}_{2} \mathrm{O}, 0.4 \% \mathrm{Na}_{2} \mathrm{CO}_{3}, 0.1 \%$ sodium fumarate, and $1 \mathrm{ppm}$ of resazurin, then incubated for $3 \mathrm{~d}$ at $39^{\circ} \mathrm{C}$. One $\mathrm{mL}$ culture was inoculated to $9 \mathrm{~mL}$ of the same fresh medium and incubated $3 \mathrm{~d}$ at $39^{\circ} \mathrm{C}$, and subculture was repeated one more time. In results, rumen fluid was enriched in $1 \%$ cellobiose medium through 3 consecutive subcultures for treatment.

Phosphate buffered saline pH 7.5 (PBS) consisted of $137 \mathrm{mM} \mathrm{NaCl}, 2.7 \mathrm{mM}$ $\mathrm{KCl}, 10 \mathrm{mM} \mathrm{Na}_{2} \mathrm{HPO}_{4}$, and $2 \mathrm{mM} \mathrm{KH}_{2} \mathrm{PO}_{4}$ and was autoclaved at $121^{\circ} \mathrm{C}$ for 30 min and stored. All procedures complied biosafety Level 1 regulation.

\subsection{Microbial Fuel Cells}

Mediator-less two chamber H-type microbial fuel cells were constructed using two $125 \mathrm{~mL}$-volume glass jars joined at branched tubular bridge. Proton exchange membrane (CMI-7000S, Membranes International Inc., NJ) was clamped between tubular bridges of two chambers and separated two chambers as anode and cathode compartments. Two gram of cellulose (Avicel PH-101, 11363 Sigma-Aldrich, MO) and $100 \mathrm{~mL}$ of anaerobic digester fluid collected from a dairy farm were transferred in anode chamber, and shortly suspended by agitation. Graphite stick $\left(12 \mathrm{~cm}^{2}\right)$ connected with copper wire was placed in the middle of anode chamber and anode was closed with butyl rubber stopper. In cathode chamber $100 \mathrm{~mL}$ of PBS was transferred and a graphite stick $\left(12 \mathrm{~cm}^{2}\right)$ connected with copper wire was placed in the middle. Butyl rubber stopper closed the cathode but open to air through tubing on stopper. Anode and cathode chambers were connected externally through a copper wires and a resistor (300 ohm). MFCs were operated in a water bath at $39^{\circ} \mathrm{C}$ for $9 \mathrm{~d}$ prior to treatment inoculation to stabilize anode electron transferring capacity and to induce anaerobic condition.

After $9 \mathrm{~d}$ of MFC operation, before treatment inoculation, current density for MFCs was $176 \pm 6.5 \mathrm{~mA} / \mathrm{m}^{2}$. One $\mathrm{mL}$ of enriched rumen culture was inoculated into anode chambers of treatment group MFCs, and $1 \mathrm{~mL}$ of pure medium was added to anode chambers of control group MFCs. Anode chamber tubings installed on butyl rubber stoppers were open to remove pressure and headspace gas, and, 2 L-volume Mylar balloons were connected to collect gas produced during experimental MFC operation.

\subsection{Measurements and Calculation}

MFC voltage across an external resistor, end point potential, and current were measured using a multimeter daily from $\mathrm{d} 0$ to $\mathrm{d} 9$. The power density normalized to electrode surface area was calculated using following equations.

$$
P=\frac{I V}{A} \text { with } I=\frac{V}{R}
$$

where, $I(A)$ is the current, $V(V)$ is voltage, $R(\mathrm{ohm})$ is the external resistance, and $A\left(\mathrm{~m}^{2}\right)$ is the projected area of the anode.

On d9, Mylar balloons connected to anode chambers were collected and total 
volume of fermentation gas produced was measured using $250 \mathrm{~mL}$-glass syringe. $\mathrm{CO}_{2}$ and methane were analyzed using an Agilent 6890 series gas chromatograph equipped with a thermal conductivity detector and a stainless steel packed column containing 60/80 Carboxen 1000 (12390-U Supelco, Sigma-Aldrich, MO) [27].

\subsection{Statistical Analyses}

Effects of enriched cellulolytic rumen microorganism addition to anaerobic digester fluid in anode chamber of MFC on electricity generation, fermentation gas production and gas composition were analyzed using the one way ANOVA procedure of JPM 12.2.0 (SAS Institute Inc., NC) and when the effect was significant $(\mathrm{P}<0.05)$, treatment means were separated using students' $t$-test. Significance was declared at $\mathrm{P}<0.05$.

\section{Results and Discussion}

\subsection{MFC Operation}

Current densities were $240 \pm 5.4 \mathrm{~mA} / \mathrm{m}^{2}$ on $\mathrm{d}$ - 1 before experiment started. MFCs were constructed with AD fluid, which was directly transferred from a dairy anaerobic digester, and cellulose as experimental substrates. MFCs have shown the utilization of $\mathrm{AD}$ efflux in electricity generation [22], therefore, in addition to supplemented cellulose, AD fluid might include nutrients (electron donors) in AD-MFCs.

Stable MFC operation during the experimental period was observed in both control and treatment groups. Open circuit voltages and currents observed were highly correlated and regression $\mathrm{r}^{2}$ were $0.98(\mathrm{P}<0.05)$ and $0.97(\mathrm{P}<0.05)$ for control and treatment group, respectively (Figure 1). Slops in regressions (Figure 1) imply the internal resistance, and slops were 947 and 965 for control and rumen fluid treatment, respectively. The high internal resistance, close to 1 $\mathrm{kOhm}$, may result from the characteristics of H-type MFC with the small area of proton exchange membrane and the long distance between anode and cathode [19]. Intercept should be zero theoretically; however was positive numbers for both treatments. Variations in voltage and current measurements and small observation number might make the intercept in equation of voltage and current. Proper MFC establishment and operation before and after treatment can be deduced from the power generation prior to treatment and the correlation of open circuit voltage and current throughout the experiment.

\subsection{Methane Production}

Total gas productions for $9 \mathrm{~d}$ incubation were 256 and $580 \mathrm{~mL}$ in control and rumen fluid treatment, respectively (Figure 4). Gases are produced from biomass fermentation, and it was much greater $(\mathrm{P}<0.05)$ when cellulolytic rumen fluid was added to AD-MFCs which containing cellulose as substrates (Figure 2). Cellulose is a linear polymer of glucose connected via beta-1,4-linkages, and it is arranged in structures of varying crystallinity [7]. Its insolubility and heterogeneity 


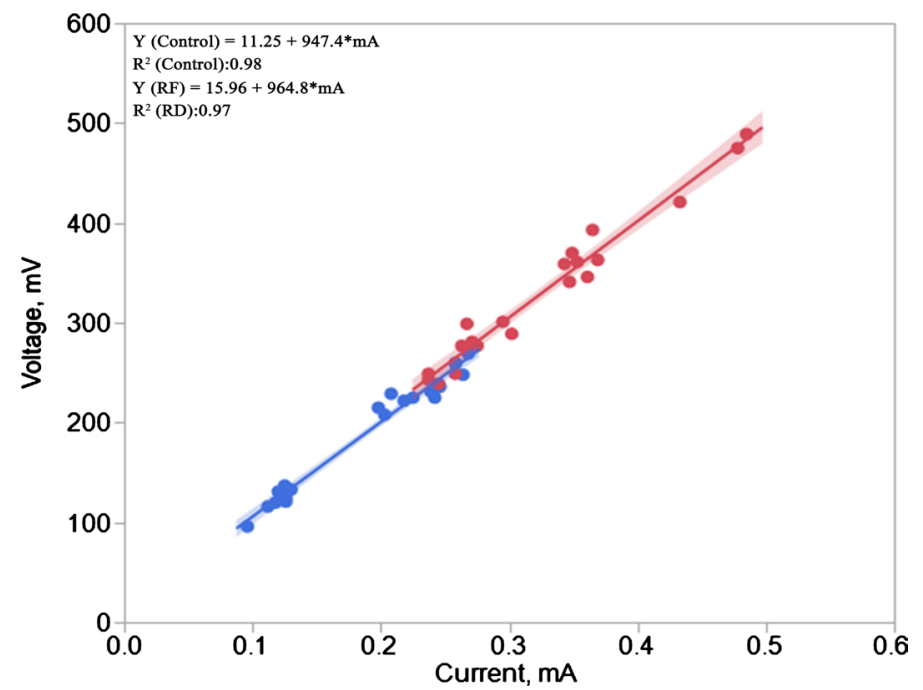

Figure 1. Open circuit end terminal voltage $(\mathrm{mV})$ and current $(\mathrm{mA})$ measured during $9 \mathrm{~d}$ of experimental period. Microbial fuel cells (MFCs) were built with $100 \mathrm{~mL}$ of dairy fecal waste from anaerobic digester and $2 \mathrm{~g}$ of cellulose (Avicel ${ }^{\mathbb{R}}$ ) and stabilized prior to treatments for $9 \mathrm{~d}$. Mixed bovine rumen contents were enriched in $1 \%$ cellobiose medium through 3 consecutive subcultures and $1 \mathrm{~mL}$ was added to anode chamber of treatment group MFCs (red circles) and an aliquot of the pure 1\% cellobiose medium without microorganism was added to control group (blue circles). MFCs were incubated at $39^{\circ} \mathrm{C}$ for $9 \mathrm{~d}$ after treatment inoculation and open circuit end terminal voltage and current were measured with $24 \mathrm{~h}$ interval. $\mathrm{R}^{2}$ of regression between current and voltage were $0.98(\mathrm{P}<$ $0.05)$ and $0.97(\mathrm{P}<0.05)$ for control and treatment, respectively.

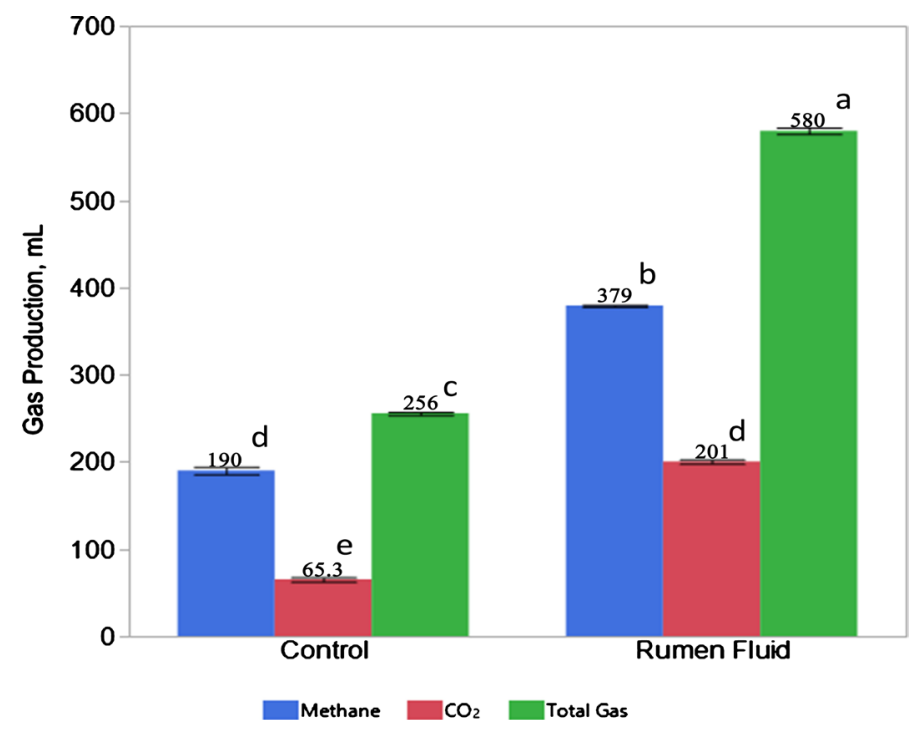

Figure 2. Accumulated gas production in the anode chamber of microbial fuel cells (MFCs). MFCs were built with $100 \mathrm{~mL}$ of dairy fecal waste from anaerobic digester and 2 $\mathrm{g}$ of cellulose (Avicel ${ }^{\circledR}$ ) and stabilized prior to treatments for $9 \mathrm{~d}$. Mixed bovine rumen contents were enriched in $1 \%$ cellobiose medium through 3 consecutive subcultures and $1 \mathrm{~mL}$ was added to anode chamber of treatment group MFCs and an aliquot of the pure $1 \%$ cellobiose medium without microorganism was added to control group. MFCs were incubated at $39^{\circ} \mathrm{C}$ for $9 \mathrm{~d}$ after treatment inoculation. Mylar balloons were connected to anode chamber of MFCs and accumulated volume of gases were measured and analyzed for gas components on d9. a, b, c, d and e mean with different superscripts differ $(\mathrm{P}<0.05)$. 
makes native cellulose a recalcitrant substrate for enzymatic hydrolysis [28]. Rumen fluid contains microorganisms which can degrade cellulose. Principle rumen cellulolytic bacteria are Fibrobacter succinogenes, Ruminococcus albus, R. flavefaciens and Butyrivibrio fibrisolvens, and also rumen cellulolytic microorganisms include fungi and protozoa [29]. In the current study, anaerobic digester fluid (AD) fermented cellulose and consequently produced gas during the 9d incubation; however its cellulolytic activity was likely much lower than inoculated rumen fluid. Impacts of rumen fluid addition on cellulose degradation reflect the establishment of rumen microbial population, which was inoculated at $1 \%(\mathrm{v} / \mathrm{v})$ dosage to $\mathrm{AD}$ community.

Methane and $\mathrm{CO}_{2}$ productions were 190 and $65 \mathrm{~mL}$, respectively, in control group, and 379 and $201 \mathrm{~mL}$, respectively, in rumen fluid treatment. The methane to $\mathrm{CO}_{2}$ ratios were 2.9 and 1.9 for control and rumen fluid treatment, respectively. Methane production was greater $(\mathrm{P}<0.05)$ in rumen fluid treatment. In the rumen, cellulose is not completely converted to $\mathrm{CO}_{2}$ and methane. Volatile fatty acids such as acetate, propionate and butyrate are significant products of cellulose fermentation in the rumen, and the predominant substrates for methanogens are $\mathrm{H}_{2}$ and $\mathrm{CO}_{2}$. In complete bioconversion systems, acetate, as well as $\mathrm{H}_{2}$ and $\mathrm{CO}_{2}$, are primary substrates for methanogens (Figure 3; [29]). For

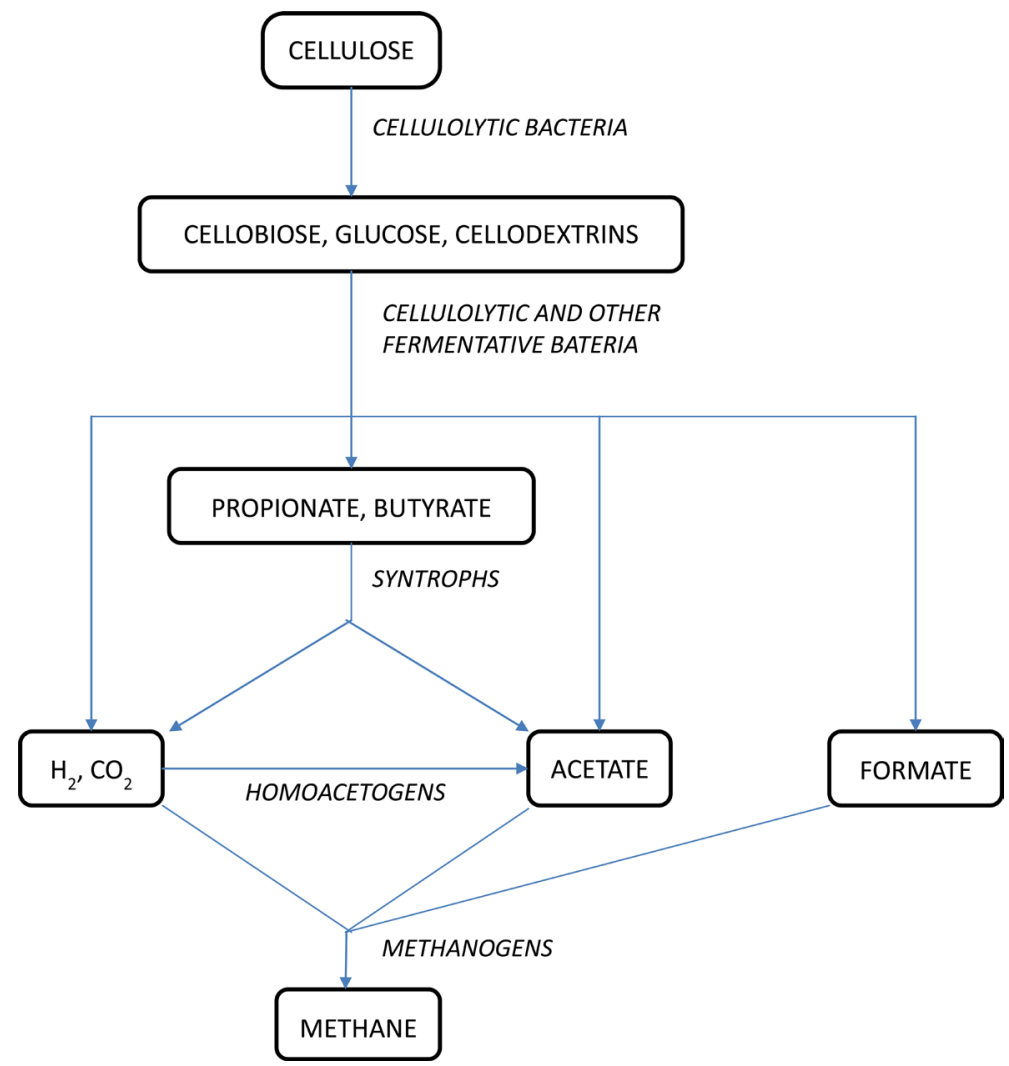

Figure 3. Diagrammatic representation of anaerobic cellulose degradation by microbial communities. Formate, volatile fatty acids (acetate, propionate, butyrate), $\mathrm{CO}_{2}$, methane are major fermentation products. Lactate, succinate, and ethanol are also produced by fermentative microorganisms but usually do not accumulate [28]. 
preparation of rumen fluid treatment in the current study, strained rumen fluid collected from forage diet fed cow passed 3 consecutive subcultures in cellobiose medium, and while cellulolytic microorganisms were enriched, other microorganisms might be diluted out. The greater amount of methane might result from symbiosis of inoculated rumen fluid and $\mathrm{AD}$ microbial communities. AD operation is to convert chemical energy in biomass to methane; therefore its microorganisms might be readily produce methane from cellulose fermentation product by rumen fluid.

\subsection{Electricity Generation}

Power generation decreased with time courses $(\mathrm{P}<0.001)$ in control MFCs. Power density gradually decreased until d5 and drastically dropped at d6 and stayed at 4 to $5 \mathrm{~mW} / \mathrm{m}^{2}$ (Figure 4). For MFC operation period, including 9d stabilization, electron donors besides supplemented cellulose might deplete in AD-MFC, and slow cellulolysis maintained the low level of power generation. Acetate and other volatile fatty acids served as electron donors for electricity generation in MFCs $\left(\mathrm{CH}_{3} \mathrm{COO}^{-}+2 \mathrm{H}_{2} \mathrm{O} \rightarrow 2 \mathrm{CO}_{2}+7 \mathrm{H}^{+}+8 \mathrm{e}^{-}\right.$; [29] $)$, therefore acetoclastic methanogenesis $\left(\mathrm{CH}_{3} \mathrm{COO}^{-}+\mathrm{H}^{+} \rightarrow \mathrm{CH}_{4}+\mathrm{CO}_{2}\right)$ does not decrease

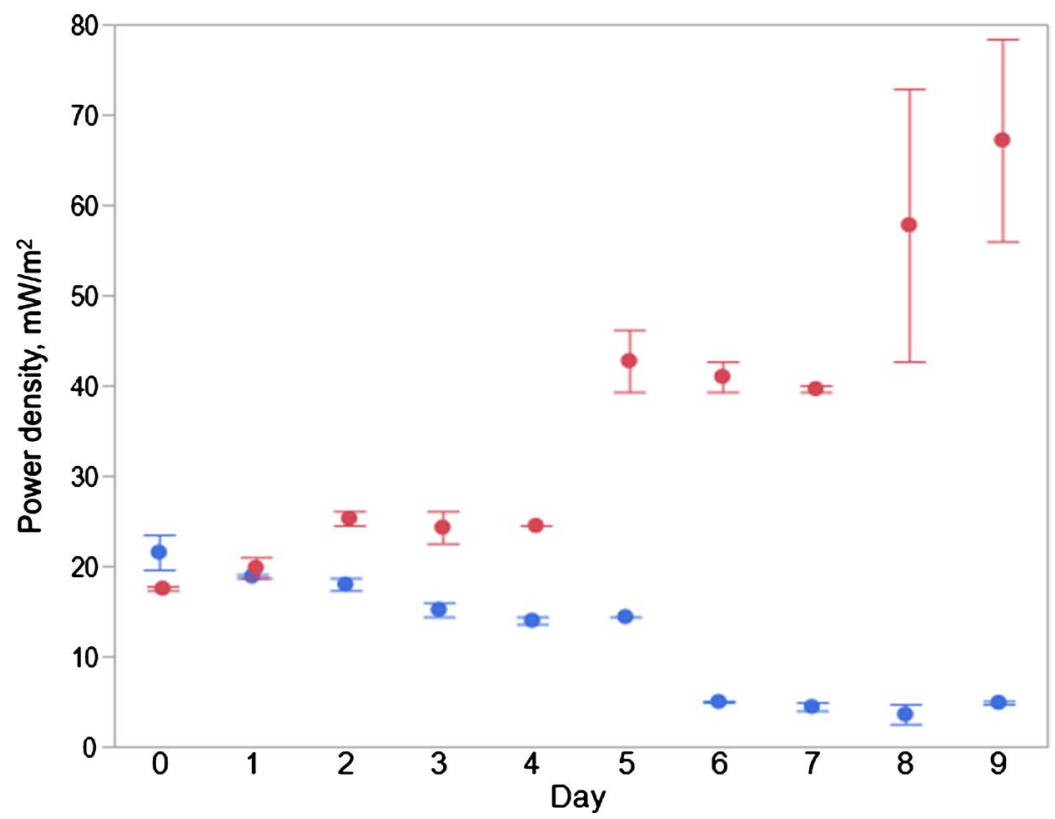

Figure 4. Changes of power densities after cellulolytic rumen fluid inoculation to microbial fuel cells (MFCs) built with dairy fecal waste from anaerobic digester and cellulose $\left(\right.$ Avicel $^{\circledR}$ ). MFCs were stabilized prior to treatments by incubation with anode chamber inocula and proton donor for $9 \mathrm{~d}$. Mixed bovine rumen contents were enriched in $1 \%$ cellobiose medium through 3 consecutive subcultures and $1 \mathrm{~mL}$ was added to anode chamber of treatment group MFCs containing $100 \mathrm{~mL}$ of anaerobic digester fluid and $2 \mathrm{~g}$ of cellulose $\left(\right.$ Avicel ${ }^{\circledR}$ ). Control group received an aliquot of the pure $1 \%$ cellobiose medium without microorganism. After treatment was added, microbial fuel cells were incubated at $39^{\circ} \mathrm{C}$ and power generation across $300 \mathrm{ohm}$ resistor was measured daily for $9 \mathrm{~d}$. For both control (blue circle) and treatment (red circle), means of power densities $(n=2)$ and standard error of mean were presented. 
only proton flow but also electrogenic substrates for electrochemically active microorganisms in AD-MFCs. Both slow cellulolysis and methane production might lower the power generation in AD-MFCs.

Power densities in rumen fluid inoculated AD-MFCs were greater $(\mathrm{P}<0.05)$ than control AD-MFC from $\mathrm{d} 2$ throughout the observation period, and increased until the end of experimental period with time $(P=0.0010$; Figure 4). Power density increased from $20-25$ to $43 \mathrm{~mW} / \mathrm{m}^{2}$ after $4 \mathrm{~d}$ and reached 67 $\mathrm{mW} / \mathrm{m}^{2}$ on $\mathrm{d} 9$. Because no single microorganism which can hydrolyze cellulose and transfer electron to electrode simultaneously has been reported, the increase in power generation with rumen fluid inoculation may result solely from the improved cellulolysis. Cellulose fermentation products by rumen fluid are mainly volatile fatty acids including acetate, propionate, and butyrate [29], and these products are readily metabolized and converted to electric energy by electrochemically active microbial community on electrode [30]. In accordance with gas production, power generation also implies the low cellulolytic activities of anaerobic digester microbial community.

Maximum power densities reported from rumen fluid researches were 55 $\mathrm{mW} / \mathrm{m}^{2}$ from microcrystalline cellulose [7], $100 \mathrm{~mW} / \mathrm{m}^{2}$ from carboxymethyl cellulose [31], and $405 \mathrm{~mW} / \mathrm{m}^{3}$ from Canna indica (canna). These previous researches focused on both cellulolysis and anode reducing activities of rumen fluid, and artificial medium were used in anolyte, and/or potassium ferricyanide $\left(\mathrm{K}_{3} \mathrm{Fe}(\mathrm{CN})_{6}\right)$ were used to enhance oxidation in cathode chamber. In addition, incubation conditions, MFC volume, electrode materials and surface area were different between studies, therefore, direct comparison is not feasible even after normalize power to geometric characteristic of the MFC reactor [32]. However all studies using rumen fluid including the current study provided the strong evidence that rumen fluid microorganisms would degrade cellulose and provide electron donor to electrochemically active microorganisms to convert chemical energy to electric power,

\section{Conclusions}

Simultaneous electricity and biomethane production from cellulose via consolidated AD-MFC using rumen fluid were demonstrated in this research. Rumen fluid inoculated at $1 \%$ dosage established population in $\mathrm{AD}$ microbial communities and increased cellulose degradation and consequently improved electricity generation and biomethane production.

New energy carrier techniques are required to reduce fossil fuel use to minimize the greenhouse gas addition to atmosphere and/or to prepare the future depletion of fossil fuels. Cellulosic biomass is the most abundant sustainable and carbon neutral resource for renewable energy production on earth; however it is also the most recalcitrant resource for biohydrolysis. Both AD and MFCs have been investigated for energy production and pollution prevention through conversion of biomass in waste to energy carriers. 
In the current study, $\mathrm{AD}$ was consolidated in $\mathrm{MFC}$, and cellulose was provided to biomass in $\mathrm{AD}$ to produce biomethane and electricity. Inoculation of rumen fluid to $\mathrm{AD}$ showed the great impact on cellulosic energy. However, further studies are required to develop rumen microbial community as inoculants. Cows cannot be maintained for inoculants production for all AD-DFMs or cellulosic energy production industry. Furthermore, cellulolytic activity and symbiosis with $\mathrm{AD}$ of rumen fluid may vary from cow to cow. Functional rumen microorganisms with the highest efficiency need to be defined and cultured. Due to complexity of cellulose biomass, studies extended to natural resources are also required to accomplish the $\mathrm{AD}-\mathrm{MFC}$.

\section{Acknowledgements}

The authors acknowledge the STEM Research Institute and Youth with Talents for sponsoring this research project.

\section{Conflicts of Interest}

The authors declare no conflicts of interest regarding the publication of this paper.

\section{References}

[1] Goldemberg, J. and Johansson, T.B. (2004) World Energy Assessment Overview: 2004 Update. United Nations Development Programme, New York.

[2] Saratale, G. and Oh, S. (2011) Production of Thermotolerant and Alkalotolerant Cellulolytic Enzymes by Isolated Nocardiopsis sp. KNU. Biodegradation, 22, 905-919. https://doi.org/10.1007/s10532-010-9450-0

[3] Lashof, D.A. and Ahuja, D.R. (1990) Relative Contributions of Greenhouse Gas Emissions to Global Warming. Nature, 344, 529-531.

https://doi.org/10.1038/344529a0

[4] Gong, M., Liu, X., Trembly, J. and Johnson, C. (2007) Sulfur-Tolerant Anode Materials for Solid Oxide Fuel Cell Application. Journal of Power Sources, 168, 289-298.

[5] Kim, I.S., Chae, K.J., Choi, M.J. and Verstraete, W. (2008) Microbial Fuel Cells: Recent Advances, Bacterial Communities and Application beyond Electricity Generation. Environmental Engineering Research, 13, 51-65.

[6] Levin, D.B., Islam, R., Cicek, N. and Sparling, R. (2006) Hydrogen Production by Clostridium Thermocellum 27405 from Cellulosic Biomass Substrates. International Journal of Hydrogen Energy, 31, 1496-1503. https://doi.org/10.1016/j.ijhydene.2006.06.015

[7] Rismani-Yazdi, H., Christy, A.D., Dehority, B.A., Morrison, M., Yu, Z. and Tuovinen, O.H. (2007) Electricity Generation from Cellulose by Rumen Microorganisms in Microbial Fuel Cells. Biotechnology and Bioengineering, 97, 1398-1407. https://doi.org/10.1002/bit.21366

[8] Perlack, R., Wright, L.L., Turhollow, A.F., Graham, A.F., Stokes, B.J. and Erbach, D.C. (2005) Biomass as Feedstock for a Bioenergy and Bioproducts Industry: The Technical Feasibility of a Billion-Ton Annual Supply. Oak Ridge National Laboratory, Oak Ridge, TN.

[9] Niessen, J., Schröder, U., Harnisch, F. and Scholz, F. (2005) Gaining Electricity from 
in situ Oxidation of Hydrogen Produced by Fermentative Cellulose Degradation. Letters in Applied Microbiology, 41, 286-290. https://doi.org/10.1111/j.1472-765X.2005.01742.x

[10] Howard, R.L., Abotsi, E., Jansen van Rensburg, E.L. and Howard, S. (2003) Lignocellulose Biotechnology: Issues of Bioconversion and Enzyme Production. African Journal of Biotechnology, 2, 602-619. https://doi.org/10.5897/AJB2003.000-1115

[11] Palmqvist, E. and Hahn-Hagerdal, B. (2000) Fermentation of Lignocellulosic Hydrolysates. I: Inhibition and Detoxification. Bioresource Technology, 74, 17-24.

[12] Mielenz, J.R. (2001) Ethanol Production from Biomass: Technology and Commercialization Status. Current Opinion in Microbiology, 4, 324-329.

https://doi.org/10.1016/S1369-5274(00)00211-3

[13] Powlson, D.S., Riche, A.B. and Shield, I. (2005) Biofuels and Other Approaches for Decreasing Fossil Fuel Emissions from Agriculture. Annals of Applied Biology, 146, 193-201. https://doi.org/10.1111/j.1744-7348.2005.040056.x

[14] Ni, M., Leung, D.Y.C., Leung, M.K.H. and Sumathy, K. (2006) An Overview of Hydrogen Production from Biomass. Fuel Processing Technology, 87, 461-472. https://doi.org/10.1016/j.fuproc.2005.11.003

[15] Lo, K., Liao, P. and Gao, Y. (1994) Anaerobic Treatment of Swine Wastewater Using Hybrid UASB Reactors. Bioresource Technology, 47, 153-157.

[16] Parawira, W., Read, J.S., Mattiasson, B. and Björnsson, L. (2008) Energy Production from Agricultural Residues: High Methane Yields in Pilot-Scale Two-Stage Anaerobic Digestion. Biomass Bioenergy, 32, 44-50. https://doi.org/10.1016/j.biombioe.2007.06.003

[17] Sakar, S., Yetilmezsoy, K. and Kocak, E. (2009) Anaerobic Digestion Technology in Poultry and Livestock Waste Treatment-A Literature Review. Waste Management \& Research, 27, 3-18. https://doi.org/10.1177/0734242X07079060

[18] Premier, G.C., Kim, J.R., Massanet-Nicolau, J., Kyazze, G., Esteves, S.R.R., Penumathsa, B.K.V., Rodríguez, J., Maddy, J., Dinsdale, R.M. and Guwy, A.J. (2013) Integration of Biohydrogen, Biomethane and Bioelectrochemical Systems. Renewable Energy, 49, 188-192. https://doi.org/10.1016/j.renene.2012.01.035

[19] Logan, B.E. and Regan, J.M. (2006) Microbial Fuel Cells-Challenges and Applications. Environmental Science \& Technology, 40, 5172-5180. https://doi.org/10.1021/es0627592

[20] EPA (2016) Inventory of U.S. Greenhouse Gas Emissions and Sinks: 1990-2014. https://www.epa.gov/sites/production/files/2016-04/documents/us-ghg-inventory-2 016-main-text.pdf

[21] Fradler, K.R., Kim, J.R., Shipley, G., Massanet-Nicolau, J., Dinsdale, R.M., Guwy, A.J. and Premier, G.C. (2014) Operation of a Bioelectrochemical System as a Polishing Stage for the Effluent from a Two-Stage Biohydrogen and Biomethane Production Process. Biochemical Engineering Journal, 85, 125-131. https://doi.org/10.1016/j.bej.2014.02.008

[22] Kim, T., An, J., Jang, J.K. and Chang, I.S. (2015) Coupling of Anaerobic Digester and Microbial Fuel Cell for COD Removal and Ammonia Recovery. Bioresource Technology, 195, 217-222. https://doi.org/10.1016/j.biortech.2015.06.009

[23] Xie, B., Liu, B., Yi, Y., Yang, L., Liang, D., Zhu, Y. and Liu, H. (2016) Microbiological Mechanism of the Improved Nitrogen and Phosphorus Removal by Embedding Microbial Fuel Cell in Anaerobic-Anoxic-Oxic Wastewater Treatment Process. Bioresource Technology, 207, 109-117. https://doi.org/10.1016/j.biortech.2016.01.090 
[24] Ishii, S., Suzuki, S., Norden-Krichmar, T.M., Nealson, K.H., Sekiguchi, Y. and Gorby, Y.A. (2012) Functionally Stable and Phylogenetically Diverse Microbial Enrichments from Microbial Fuel Cells during Wastewater Treatment. PLoS ONE, 7, e30495. https://doi.org/10.1371/journal.pone.0030495

[25] Desvaux, M., Guedon, E. and Petitdemange, H. (2000) Cellulose Catabolism by Clostridium Cellulolyticum Growing in Batch Culture on Defined Medium. Applied and Environmental Microbiology, 66, 2461-2470. https://doi.org/10.1128/AEM.66.6.2461-2470.2000

[26] Krause, D.O., Denman, S.E., Mackie, R.I. and Morrison, M. (2003) Opportunities to Improve Fiber Degradation in the Rumen: Microbiology, Ecology, and Genomics. FEMS Microbiology Reviews, 27, 663-693. https://doi.org/10.1016/S0168-6445(03)00072-X

[27] Chung, R., Moon, D., Chang, Y., Chung, D., Kong, T. and Kim, J. (2018) The Cellulolytic Bacteria $R$. albus for Improving the Efficiency of Microbial Fuel Cell. Journal of Sustainable Bioenergy Systems, 8, 36-46. https://doi.org/10.4236/jsbs.2018.82003

[28] Schwarz, W.H. (2001) The Cellulosome and Cellulose Degradation by Anaerobic Bacteria. Applied Microbiology and Biotechnology, 56, 634-649. https://doi.org/10.1007/s002530100710

[29] Leschine, S.B. (1995) Cellulose Degradation in Anaerobic Environments. Annual Review of Microbiology, 49, 399-426. https://doi.org/10.1146/annurev.mi.49.100195.002151

[30] Freguia, S., The, E.H., Boon, N., Leung, K.M., Keller, J. and Rabaey, K. (2010) Microbial Fuel Cells Operating on Mixed Fatty Acids. Bioresource Technology, 101, 1233-1238. https://doi.org/10.1016/j.biortech.2009.09.054

[31] 31-Wang, Z.Q., Hong, M., Shu, Y., Chen, Y., Dong, L.X. and Ming, Y. (2014) Rumen Bacteria Convert Cellulose into Electricity in Two-Chamber Microbial Fuel Cell. Journal of Chemical and Pharmaceutical Research, 6, 727-732.

[32] Choi, S. (2015) Microscale Microbial Fuel Cells: Advances and Challenges. Biosensors Bioelectronics, 69, 8-25. 